\title{
Evaluation of fermented cassava (Manihot esculenta Crantz) pulp as feed ingredient for broiler
}

\author{
Ahmad Darobin Lubis ${ }^{1}$, Suhartono ${ }^{1}$, Budi Darmawan ${ }^{1}$, Hasta Ningrum ${ }^{1}$, Ika Yunitha \\ NOORMASARI $^{1}$ and Nobukazu NAKAgOSHI ${ }^{2}$ \\ Faculty of Animal Science, Bogor Agricultural University, Rasamala Street, Darmaga, Bogor, Indonesia. \\ Graduate School for International Development and Cooperation, Hiroshima University, 1-5-1 Kagamiyama, Higashi-Hiroshima, 739-8529, \\ Japan. \\ Tel: 082-424-5973, Fax: 082-424-6904, E-mail: darobin21@yahoo.com
}

\begin{abstract}
Cassava pulp is a solid waste that is produced as a byproduct of starch production in tropical regions. This product still contains high levels of starch, and constitutes a serious environmental concern as a disposal. Cassava pulp can be used as feed for poultry by enriching the protein content (CP). Cassava pulp was added with $3 \%$ urea and $2.5 \%$ zeolite (clinoptilolite) and was fermented by Aspergillus niger for six days. Due to $\mathrm{CP}$ and crude fiber concentration, it was formed good in quality. Fermented cassava pulp-urea-zeolite had the lowest true metabolized energy compared with rice bran and unfermented cassava pulp $(2,524$ $\mathrm{kcal} / \mathrm{kg}$ vs. 3,310 and $2,959 \mathrm{kcal} / \mathrm{kg}$, respectively). However, this product had the highest efficiency of protein utilization ( $72 \%$ vs. 39 and $41 \%$, respectively). Broilers were fed diets containing 0 , 5,10 , or $15 \%$ fermented cassava pulp-urea-zeolite with a commercial diet used for comparison ratio. All treatment diets had no significant effect on the body weight gain, feed conversion, yield of carcass, internal organs and abdominal fat as compared with broiler fed with commercial diet. Results suggest that fermented cassava pulp-urea-zeolite can successfully constitute up to $15 \%$ of the diet of broilers without causing health problem.
\end{abstract}

Keywords: Aspergillus niger, cassava pulp, urea, zeolite

\section{INTRODUCTION}

World production of cassava has increased from 75 million tonnes in 1961-1965 to 153 million tonnes in 1991 (FAO, 1995). Five countries account for $67 \%$ of the world cassava production i.e. Nigeria, Brazil, Thailand,
Zaire and Indonesia. Indonesia produces 16 million tonnes of fresh cassava (Manihot esculenta) roots yearly (Indonesian Central Bureau Statistic, 2000). Most of the products used in cassava starch industries results in the creation of around $10-15 \%$ of the root as solid state waste (pulp) (Sriroth et al. 2000). Cassava pulp in some areas is used as a fermented subtrate in citric acid production. However, some of the pulp is discarded and becomes a serious concern to the environment especially air (odor) and water pollution. Cassava pulp can be used as animal feed, but, its nutrient quality is low especially in crude protein concentration (less than 2\%) (Pandey, 2000).

Protein enrichment of cassava pulp using microbial techniques is an alternative way to improve the quality. Prescott and Dun (1982) reported that this byproduct can be used as a substrate in fermentation of microorganism. Among the microorganisms, Aspergillus niger has been reported to be good to ferment cassava by product (Iyayi and Losel, 2001; Pandey, 2000; Verdenberghe et al. 1999). Aspergillus niger can utilize different kinds of food ranging from simple to complex ones. This makes them easy to cultivate and maintain in the field. However, the fermentation processes need more nitrogen and minerals for their growth and reproduction. According to Pepler (1973), the addition of some nutrients in the fermentation media will enhance the fermentation process and the quality of final product. Urea is one of non protein nitrogen source that is normally used by some microorganisms in the fermentation process (Brook et al. 1969). Garraway and Evans (1984) reported that urea when used in fermentation breaks down to ammonium and carbon dioxide. The ammonium produced will be used by microorganisms to synthesize their body cells. However, ammonium production from urea is four times faster than synthesis of microorganisms' body cell from ammonium. A high ammonium concentration is toxic for 
the organisms involved in the fermentation process itself (Hendriksen and Ahrig, 1991). Zeolite (clinoptilolite) can be used as a reservoir to maintain the ammonia level during fermentation. Clinoptilolite has a preference for big ion such as $\mathrm{NH}_{4}^{+}$, so it would act as an ammonia reservoir, slowing its transit and allowing its gradual release. According to Pond \& Mumpton (1984), studies in Japan using less than 10\% clinoptilolite in swine and poultry rations resulted in faster growth than control groups and reduced smell in manure and litter. Ramos and Hernandes (1997) reported that zeolite in poultry feed can prevent them being contaminated by aflatoxin. The objective of this experiment is to evaluate fermented cassava pulp-urea-zeolite combination as a feed ingredient for broilers.

\section{MATERIALS AND METHODS}

Dry cassava pulp was obtained from cassava starch industry in Bogor, Indonesia, and then ground with a hammer mill. The experiment comprised of 16 substrate combination of four levels of urea $(0,3,6$, and $9 \%)$ and four levels of natural zeolite (clinoptilolite) from Bayah, West Java (0, 2.5, 5 and 7.5\%). All substrates were sterilized at a temperature of $120^{\circ} \mathrm{C}$ for 15 minutes. Solid substrates were inoculated with $A$. niger $\left(10^{7}\right.$ spores $/ \mathrm{g}$ of dry matter substrate, inoculum's size), mixed with urea and sterilized water to increase the moisture of the substrates (about 75\%). Fermentation was carried out in plastic bags with pores for aerobic fermentation and then kept in incubator with temperature of $28-32^{\circ} \mathrm{C}$ for six days. The fermented products were analyzed for dry matter (DM), crude ash (CA), crude protein (CP), ether extract (EE), crude fiber $(\mathrm{CF})$, and nitrogen free extract (NFE) by the method of AOAC (1984). All data were analyzed using two way analyses of variance (ANOVA) and Duncan's new multiple range test procedure by Steel and Torrie (1980).

The result from above experiment was used in this experiment. The combination of $3 \%$ urea and $2.5 \%$ zeolite fermented with $A$. niger with the method used in above experiment and incubated for four, six, eight and ten days. All products were analyzed for $\mathrm{CA}, \mathrm{CP}$, $\mathrm{CF}$ and gross energy (GE) by the method of AOAC (1984). All data were analyzed using one way analyses of variance (ANOVA) and Duncan's new multiple range test procedure by Steel and Torrie (1980).

A combination of $3 \%$ urea and $2.5 \%$ zeolite fermented with $A$. niger for six days was used in this experiment. Samples were evaluated as chicken feed according to its true metabolized energy (TME) and efficiency of protein utilization (EPU) compared with unfermented cassava pulp and rice bran. True metabolized energy was determined by the method of Sibbald (1980), using 12 heads of mature native chicken (1.5 year old). The native chickens were housed in individual metabolic cage and starved for 24 hours to empty their alimentary canals of feed residues. Three replicates were used for each treatment (fermented cassava pulp-urea-zeolite, unfermented cassava pulp and rice bran) and the other 3 chickens were used to assess the fecal energy of metabolic origin (derived from abraded intestinal mucosa, bile, digestive fluid, etc.). Nine native chickens used on the treatment diets were force-fed with 20 gram for each treatment, while, the other 3 chickens were not fed. Chickens were force-fed because this ensures that the amount and time of the feed entering the chickens was controlled. A funnel, which had a stem $40 \mathrm{~cm}$ long and 1.3 $\mathrm{cm}$ in external diameter, was pushed down the esophagus until it entered the crop. The weighed feed was poured from its plastic container into the funnel and pushed into the crop with a plunger. Exactly 24 hours after putting chickens in the metabolic cages, their excreta was collected, frozen, dried and weighted. Samples of the feeds and excreta were ground and assayed for CP and GE concentration (AOAC, 1984). True metabolized energy was calculated using the formula:

TME $(\mathrm{kcal} / \mathrm{kg})=\left\{\left(\right.\right.$ Fin ${ }^{*}$ GEfs $)-($ GEex-GEen $\left.)\right\} /$ Fin

where:

$\mathrm{Fi} \quad=$ feed intake $(\mathrm{kg})$

GEfs = gross energy of the feedstuffs $(\mathrm{kcal} / \mathrm{kg})$

GEex = gross energy in excreta from the fed chicken (kcal/kg)

GEen = gross energy in excreta from unfed chicken.

While, EPU was calculated using the formula: EPU $(\%)=\{($ Fin * CPfs $)-($ CPex-CPen $)\} /\left(\right.$ Fin ${ }^{*}$ CPfs $) * 100$ where:

$\mathrm{Fi} \quad=$ feed intake $(\mathrm{g})$

CPfs = crude protein of the feedstuffs $(\mathrm{g})$

$\mathrm{CPex}=$ crude protein in excreta from the fed chicken $(\mathrm{g})$

$\mathrm{CPen}=$ crude protein in excreta from unfed chicken $(\mathrm{g})$

All data were analyzed by using one way analyses of variance (ANOVA) and Duncan's new multiple range test procedure by Steel and Torrie (1980).

Day old chicks (DOC) of broiler-type were obtained from a commercial hatchery. Experiment was conducted in electrically heated brooders with wire mesh floor. Feed and water were provided ad libitum. An experiment used DOC of 200 Hybro broilers to evaluate the nutritional value of fermented cassava pulp-urea-zeolite. Four replications 
of ten chicks were randomly assigned to each treatment as shown in Table 1 and compared with a commercial diet. The experimental diets were prepared isocaloric and isonitrogenous due to their nutrient requirements (Scott et al. 1982; NRC, 1994). All experiment diets were fed in mash form. Body weight gain and feed consumption data were recorded at every week of age. At six weeks of ages, four broilers from each treatment were selected randomly and processed through the Bogor Agricultural University, Poultry Laboratory where carcass yields were obtained. Concurrent with these measurements, weight of liver, heart, gizzard, kidney and abdominal fat were recorded. Simple randomized design was used and data were analyzed by one-way classification analysis of variance. The treatments mean differences were tested by Duncan's multiple range test (Steel and Torrie, 1980).

\section{RESULTS}

The proximate nutritional composition of unfermented cassava pulp was DM (95.04\%), CA (0.85\%), CP (2.21\%),
CF (11.16\%), EE (0.33\%) and NFE (85.45\%). Chemical composition of combined fermented cassava pulpurea-zeolite is shown in Table 2. Crude fiber and NFE concentration were significantly lower $(\mathrm{P}<0.05)$ with $3 \%$ of urea, however, after $3 \%$ urea, an increase of their concentration was observed. On the other hand, $\mathrm{CP}$ and EE concentration increased with $3 \%$ of urea, and then their concentration decreased again with 6 and $9 \%$ of urea concentration. There were no significant effect of zeolite on DM, EE, and CP concentration. Crude ash concentration increased with the level of zeolite, while NFE concentration decreased. Crude fiber concentration increased up to $5 \%$ of zeolite, then its value decreased again with the application of $7.5 \%$ zeolite, except for $3 \%$ urea, there were no significant difference among $0,2.5$, 5 and $7.5 \%$ of zeolite. The crude protein concentration of fermented cassava pulp with $3 \%$ urea was comparable with rice bran (Hartadi et al. 1991)

Effect of different fermentation periods on the chemical composition of fermented cassava pulp-ureazeolite are shown in Table 3. There was no significant

Table 1. Percentage of ingredients and calculated composition of broiler diets (\% on air-dry basis).

\begin{tabular}{lrrrr}
\hline Ingredients (\%) & Ration 1 & Ration 2 & Ration 3 & Ration 4 \\
\hline Yellow corn & 35.40 & 37.00 & 35.50 & 33.70 \\
Rice bran & 24.80 & 17.00 & 13.70 & 10.00 \\
Soybean meal & 24.50 & 24.80 & 24.70 & 24.70 \\
Fish meal & 9.60 & 9.60 & 9.60 & 9.60 \\
Coconut oil & 3.00 & 3.40 & 3.80 & 4.30 \\
Fermented Cassava pulp & 0.00 & 5.00 & 10.00 & 15.00 \\
CaCO $_{3}$ & 1.00 & 1.00 & 1.00 & 1.00 \\
Mineral mixture & 0.50 & 0.50 & 0.50 & 0.50 \\
DCP & 1.00 & 1.00 & 1.00 & 1.00 \\
DL-Methionin & 0.20 & 0.20 & 0.20 & 0.20 \\
& 100.00 & 100.00 & 100.00 & 100.00 \\
& & & & \\
Calculated composition & & & & 3003.47 \\
Metabolizable energy (kcal/kg) & 3000.01 & 3007.41 & 3002.63 & 22.73 \\
Crude protein (\%) & 22.75 & 22.70 & 22.71 & 1.24 \\
Lysin (\%) & 1.33 & 1.29 & 1.27 & 0.39 \\
Methionin (\%) & 0.44 & 0.42 & 0.41 & 0.70 \\
Methionin + Cystin (\%) & 0.78 & 0.75 & 0.73 & 1.21 \\
Calsium (\%) & 1.18 & 1.19 & 1.20 & 0.57 \\
Phosphorus available (\%) & 0.61 & 0.59 & 0.59 & 8.08 \\
Ether extract (\%) & 8.67 & 8.15 & 8.10 & 5.59 \\
Crude fiber (\%) & 5.39 & 5.19 & 5.41 &
\end{tabular}


Table 2. Effects of levels urea and zeolite on chemical composition of fermented cassava pulp-urea-zeolite (\% on a dry matter basis).

\begin{tabular}{|c|c|c|c|c|c|c|c|}
\hline \multicolumn{2}{|c|}{ Treatments } & \multicolumn{6}{|c|}{ Chemical composition } \\
\hline $\begin{array}{c}\text { Urea } \\
(\%)\end{array}$ & Zeolite & $\mathrm{DM}$ & $\mathrm{CA}$ & $\mathrm{EE}$ & $\mathrm{CP}$ & $\mathrm{CF}$ & NFE \\
\hline 0.0 & 0.0 & 94.91 & 1.19 & 0.19 & 3.58 & 16.99 & 78.18 \\
\hline 0.0 & 2.5 & 91.75 & 4.14 & 0.41 & 5.49 & 16.75 & 73.21 \\
\hline 0.0 & 5.0 & 92.89 & 7.37 & 0.44 & 2.78 & 17.22 & 72.18 \\
\hline 0.0 & 7.5 & 94.69 & 10.36 & 0.69 & 3.29 & 12.42 & 73.24 \\
\hline 3.0 & 0.0 & 89.82 & 1.02 & 0.60 & 13.80 & 13.52 & 71.05 \\
\hline 3.0 & 2.5 & 93.03 & 4.33 & 0.66 & 12.97 & 12.73 & 69.31 \\
\hline 3.0 & 5.0 & 89.60 & 7.36 & 0.72 & 14.00 & 11.96 & 65.96 \\
\hline 3.0 & 7.5 & 93.64 & 10.85 & 0.58 & 13.62 & 11.99 & 62.95 \\
\hline 6.0 & 0.0 & 95.11 & 1.21 & 0.55 & 7.66 & 8.52 & 82.06 \\
\hline 6.0 & 2.5 & 92.25 & 4.60 & 0.49 & 7.72 & 10.43 & 76.76 \\
\hline 6.0 & 5.0 & 94.91 & 7.75 & 0.67 & 5.93 & 18.30 & 67.35 \\
\hline 6.0 & 7.5 & 95.01 & 10.72 & 0.41 & 3.23 & 16.81 & 68.83 \\
\hline 9.0 & 0.0 & 95.03 & 1.04 & 0.33 & 5.48 & 10.67 & 82.47 \\
\hline 9.0 & 2.5 & 95.67 & 4.55 & 0.30 & 4.95 & 11.30 & 78.90 \\
\hline 9.0 & 5.0 & 95.37 & 7.28 & 0.25 & 8.79 & 6.43 & 77.25 \\
\hline 9.0 & 7.5 & 95.89 & 10.47 & 0.24 & 7.60 & 6.19 & 75.49 \\
\hline \multicolumn{8}{|l|}{ Significancy } \\
\hline Urea & & $\mathrm{ns}$ & $\mathrm{ns}$ & $*$ & $* *$ & $* *$ & $* *$ \\
\hline Zeolite & & ns & $* *$ & ns & ns & $*$ & $* *$ \\
\hline Interaction & & ns & ns & ns & $*$ & $* *$ & $*$ \\
\hline
\end{tabular}

DM, dry matter; CA, crude ash; EE, ether extraxt; $\mathrm{CP}$, crude protein; $\mathrm{CF}$, crude fiber; NFE, nitrogen free extract; ns, not significant; ${ }^{*},{ }^{* *}$ significant at 5 and $1 \%$ levels, respectively.

difference on CA concentration with length of fermentation time. However, CP concentration increased $(\mathrm{P}<0.05)$ significantly up to eight days of fermentation. Thereafter, CP concentration decreased. On the other hand, $\mathrm{CF}$ concentration decreased for up to eight days of fermentation, thereafter, the concentration decreased again. Crude protein and $\mathrm{CF}$ concentration were not significantly different between six and eight days of fermentation. Gross energy decreased for up to six days of fermentation, and then the value was not significantly changed up to ten days of fermentation.

True metabolized energy and efficiency of protein utilization of fermented cassava pulp combined with $3 \%$ of urea and $2.5 \%$ of zeolite for six days of fermentation compared with unfermented cassava pulp and rice bran is shown in Table 4. There were no significant differences in energy intake and energy in excreta among treatments. Fermented cassava pulp-urea-zeolite had the lowest TME compared with unfermented cassava pulp and rice bran $(2,523.54 \mathrm{kcal} / \mathrm{kg}$ vs. $2,958.66$ and $3,310.46 \mathrm{kcal} /$ $\mathrm{kg}$, respectively). Although protein retention between fermented cassava pulp-urea-zeolite and rice bran were not significantly different, the efficiency of protein utilization of fermented cassava pulp-urea-zeolite was higher (71.67\% vs. $38.91 \%)$.

There were no significant differences in all performance parameters and internal organs among treatments as shown in Table 5. The fact that intakes did not differ in all treatments might be due to the crude fiber and palatability, almost same in all diets. Moreover, all broilers were subjected to the same environmental management. Similar genetic, management and feeding intake resulted in the same body weight gain and feed conversion ratio of broilers. There was no health problem among broilers that were fed with fermented cassava pulp-urea-zeolite due to the normal weight of internal organ as shown in Table 5. 
Table 3. Effects period of fermentation on chemical composition of cassava pulp-urea-zeolite (\% on a DM basis).

\begin{tabular}{|c|c|c|c|c|c|c|}
\hline \multirow[b]{3}{*}{ Crude ash (\%) } & \multicolumn{6}{|c|}{ Fermentation periods (days) } \\
\hline & 4 & 6 & \multicolumn{2}{|c|}{8} & \multicolumn{2}{|l|}{10} \\
\hline & $4.06 \pm 0.09$ & $4.05 \pm$ & $4.77 \pm$ & 0.07 & $5.04 \pm$ & 0.35 \\
\hline Crude Protein (\%) & $4.87 \pm 1.85^{\mathrm{a}}$ & $8.03 \pm$ & $8.35 \pm$ & $2.26^{\mathrm{b}}$ & $5.24 \pm$ & $0.33^{\mathrm{a}}$ \\
\hline Crude Fiber (\%) & $7.81 \pm 0.60^{a}$ & $6.47 \pm 0.49^{\mathrm{b}}$ & $6.64 \pm$ & $0.94^{\mathrm{b}}$ & $8.10 \pm$ & $0.12^{\mathrm{a}}$ \\
\hline Gross Energy (cal/g) & $3912.67 \pm 59.43^{\mathrm{a}}$ & $3539.33 \pm 177.89^{b}$ & $3541.67 \pm$ & $144.78^{b}$ & $3536.60 \pm 1$ & $59.90^{\mathrm{b}}$ \\
\hline
\end{tabular}

Means with different superscripts within the same row are significantly different $(\mathrm{P}<0.05)$

Table 4. True metabolizable energy and efficiency of protein utilization of rice bran, fermented and unfermented cassava pulp-urea-zeolite (\% on air-dry basis).

\begin{tabular}{|c|c|c|c|c|}
\hline & & Rice bran & $\begin{array}{l}\text { Unfermented } \\
\text { cassava pulp }\end{array}$ & $\begin{array}{c}\text { Fermented cassava } \\
\text { pulp }\end{array}$ \\
\hline \multicolumn{5}{|l|}{ Energy } \\
\hline & Energy intake (kcal) & 86.84 & 64.84 & 70.79 \\
\hline & Energy in excreta (kcal) & $31.36 \pm 2.50$ & $16.59 \pm 133.98$ & $31.24 \pm 1.00$ \\
\hline & Apparent metabolized energy $(\mathrm{kcal} / \mathrm{kg})$ & $2764.14 \pm 124.91^{\mathrm{a}}$ & $2412.34 \pm 133.99^{\mathrm{b}}$ & $1977.21 \pm 50.03^{\mathrm{c}}$ \\
\hline & True metabolized energy (kcal/kg) & $3310.46 \pm 129.91^{a}$ & $2958.66 \pm 177.89^{\mathrm{b}}$ & $2523.54 \pm 50.03^{c}$ \\
\hline \multicolumn{5}{|l|}{ Protein } \\
\hline & Protein intake $(\mathrm{g})$ & 2.42 & 0.23 & 1.01 \\
\hline & Protein in excreta $(g)$ & $3.27 \pm$ & $1.93 \pm 0.05$ & $2.08 \pm 0.14$ \\
\hline & Endogenous protein $(\mathrm{g})$ & 1.79 & 1.79 & 1.79 \\
\hline & Protein retention $(g)$ & $0.94 \pm 0.52^{\mathrm{a}}$ & $0.09 \pm \quad 0.55^{b}$ & $0.72 \pm 0.14^{\mathrm{a}}$ \\
\hline & Efficiency of protein utilization (\%) & $38.91 \pm 21.33^{\mathrm{a}}$ & $40.89 \pm 23.44^{\mathrm{b}}$ & $71.67 \pm 13.87^{\mathrm{c}}$ \\
\hline
\end{tabular}

Means with different superscripts within the same row are significantly different $(\mathrm{P}<0.05)$

Table 5. Effects of treatments on performance of broilers for 6 weeks of experiment.

\begin{tabular}{|c|c|c|c|c|c|}
\hline Parameters & Ration 1 & Ration 2 & Ration 3 & Ration 4 & $\begin{array}{l}\text { Commercial } \\
\text { ration }\end{array}$ \\
\hline Body weight (g) & $41.92 \pm$ & $40.60 \pm 3.20$ & $40.59 \pm$ & $41.00 \pm 3.50$ & $41.82 \pm$ \\
\hline Intake $(g)$ & $2949.52 \pm 192.52$ & $2887.05 \pm 222.32$ & $2790.80 \pm 138.43$ & $2882.70 \pm 166.03$ & $3107.04 \pm 101.26$ \\
\hline Body weight gain (g) & $258.94 \pm 13.70$ & $255.68 \pm 24.18$ & $240.83 \pm 12.24$ & $252.24 \pm 13.28$ & $291.51 \pm 12.52$ \\
\hline Final weight $(g)$ & $1612.69 \pm 69.33$ & $1589.32 \pm 136.53$ & $1527.19 \pm 75.42$ & $1572.99 \pm 64.07$ & $1809.60 \pm 59.64$ \\
\hline Feed conversion ratio & $1.79 \pm \quad 4.00$ & $1.76 \pm$ & $1.81 \pm 0.11$ & $1.77 \pm$ & $1.64 \pm$ \\
\hline Carcass (g) & $1098.33 \pm 57.95$ & $1100.00 \pm 98.49$ & $955.00 \pm 65.00$ & $1065.00 \pm 81.85$ & $1256.67 \pm 66.53$ \\
\hline \multicolumn{6}{|l|}{ Internal organs (\%) } \\
\hline Liver & $2.29 \pm$ & $2.04 \pm$ & $2.56 \pm$ & $2.19 \pm$ & $2.17 \pm$ \\
\hline Gizzard & $2.22 \pm$ & $2.21 \pm$ & $2.23 \pm$ & $2.14 \pm$ & $1.83 \pm$ \\
\hline Heart & $0.54 \pm$ & $0.49 \pm$ & $0.60 \pm$ & $0.49 \pm$ & $0.49 \pm$ \\
\hline Kidney & $0.27 \pm$ & $0.26 \pm$ & $0.29 \pm$ & $0.22 \pm$ & $0.21 \pm$ \\
\hline Abdominal fat (\%) & $0.92 \pm$ & $1.08 \pm$ & $0.80 \pm$ & $1.13 \pm$ & $1.55 \pm$ \\
\hline
\end{tabular}

Ration 1, Diet without fermented cassava pulp; ration 2, fermented cassava pulp 5\%, Ration 3, fermented cassava pulp 10\%;

Ration 4, fermented cassava pulp 15\%; 


\section{DISCUSSION}

Chemical composition of fermented cassava pulp combined with $3 \%$ of urea and $2.5 \%$ of zeolite for six days of fermentation had better nutritional value due to the $\mathrm{CP}$ and $\mathrm{CF}$ concentration. Crude protein in cassava pulp in this experiment was higher than that reported by Iyayi and Losel (2001). They improved the CP concentration of fermented cassava pulp with $A$. niger from $3.6 \%$ to $8.10 \%$ and $8.15 \%$ after 5 and 10 days of fermentation, respectively. Higher CP concentration in this experiment might be caused by the addition of urea in the substrate. Wang et al. (1979) reported that the addition of urea in fermentation medium increased microorganism's body cells. Although zeolite had no effect on CP concentration, zeolite as an ammonia reservoir could release ammonia to the fermentation process gradually. Therefore microorganisms can use it to synthesize their body cells protein more efficiently.

Barbarick and Pirela (1984) reported that zeolites are clay like mineral mined from sedimentary deposit that contained some minerals needed by microorganisms for their growth such as $\mathrm{Na}^{+}, \mathrm{Ca}^{2+}, \mathrm{K}^{+}, \mathrm{Mg}^{2+}, \mathrm{Sr}^{2+}$ and $\mathrm{Ba}^{2+}$. Therefore, the CA concentration of fermented cassava pulp increased with levels of zeolite. There were significant increases of $\mathrm{CP}$ concentration and decreases of CF concentration of cassava pulp-urea-zeolite from 0 to 6 days of fermentation, then no change in value within 6 to 10 days of fermentation. Iyayi and Losel (2001) found that the $\mathrm{CP}$ of cassava pulp fermented with $A$. niger increased significantly from day 0 to day 5 of fermentation, and thereafter there were no further significant change. Differences in $\mathrm{CP}$ and $\mathrm{CF}$ concentration in fermented cassava pulp-urea-zeolite relative to days of fermentation might be related to the time used by microorganisms for their growth and reproduction. Less than 4 days was not enough for microorganisms to grow and produce cellulase enzyme to break down cellulose in substrate. However, when the length of fermentation was more than ten days, $A$. niger reached a stationary phase, as its ability to grow and produce cellulase enzyme decreased, thus the concentration of $\mathrm{CP}$ decreased and $\mathrm{CF}$ increased again.

The chemical composition of fermented cassava pulp with $3 \%$ of urea and $2.5 \%$ of zeolite is similar to that of rice bran due to its $\mathrm{CP}$ and $\mathrm{CF}$ concentration (Hartadi et al. 1997). Therefore, rice bran was used as comparison in the TME and EPU experiment. However, the $\mathrm{CP}$ concentration of fermented cassava pulp used was lower than that of previous experiment. Lower CP concentration could have been due to length of storage before using it for about two weeks. According to Hall (1980) storing time would decrease the protein content of feed. Native chicken fed by rice bran had the highest energy intake followed by fermented cassava pulp-ureazeolite then unfermented cassava pulp. Energy in excreta from chicken fed by fermented cassava pulp-urea-zeolite was higher than that from chicken fed by unfermented cassava pulp, however, it was not different than from chicken fed by rice bran (Table 4). Difference in energy excreta of chicken fed by fermented and unfermented cassava pulp might be due to the fermentation process (DeMan, 1977). Fermentation process could produce substrate which cannot be hydrolyzed by digestive enzymes (Wang et al. 1979). The difference in energy intake and energy in excreta among samples will cause the difference in their TME as shown in Table 4 (Sibbald, 1980). The lowest TME in fermented cassava pulp-ureazeolite could be attributed by the ability of $A$. niger to hydrolyze starch into glucose and that will be used as a carbon source to synthesize its biomass that is rich in protein (Oboh, 2005). Therefore, starch or other unstructured carbohydrates as a main energy source for chicken decreased in the substrate.

Rice bran had the highest protein intake compared with fermented cassava pulp-urea-zeolite and unfermented cassava pulp (2.42g vs. $1.61 \mathrm{~g}$ and $0.23 \mathrm{~g}$, respectively). Scott et al. (1982) reported that protein retention depends on protein intake and metabolized energy in ration. However, increasing energy metabolized in ration does not always increase protein retention. Increasing protein intake will be followed by an increase in protein retention, however, the body weight gain is not always increased if the energy concentration in ration is low. Protein retention of unfermented cassava pulp was the lowest compared with fermented cassava pulp-urea-zeolite and rice bran. Although there was no significant difference in protein retention between fermented cassava-urea-zeolite and rice brand, fermented cassava pulp-urea-zeolite had the highest EPU. Higher EPU of feedstuff will produce higher protein that is used by animal for their growth and production (Scott et al. 1982).

There were no significant difference on the performance parameters among treatments and this might be caused by the environmental management. Also, the diets were isocaloric and isonitrogenous and there were no differences in the palatability of the diets based on the amount of their intake (Table 5). Feed conversion ratios of this experiment were better than those of experiments done by Haroen (1993) that used 
unfermented cassava pulp in broiler diet (15\%) i.e. 2.22. The better feed conversion value of this experiment might be because of higher protein concentration and efficiency of protein utilization in fermented cassava pulp-urea-zeolite (Table 4). Carcass measures of 65 to $71 \%$ were normal for the broiler (Lesson and Summers 1980). Using fermented cassava pulp-urea-zeolite in the diets did not significantly influence the relative organs weight of the liver, gizzard, heart, and kidney. Increasing the amount of fermented cassava pulp-urea-zeolite in the diets did not significantly increase these organs' weight suggesting that broilers grew normally without any extra effort required to digest or metabolize fermented cassava pulp-urea-zeolite. Percentages of all organs in this experiment were normal according to data reported by Putnam (1991). Abdominal fat is one factor that decreases the taste of broiler meat for consumer. Accumulation of abdominal fat was considered as a byproduct and scattered energy of diet. Sundari (1996) reported that abdominal fat could be reduced by increasing the fiber concentration of diet. However, there was no significant effect of increasing fermented cassava pulp-urea-zeolite up to $15 \%$ in the diet. Abdominal fat percentages of all broilers among treatment were in the range reported by Lesson \& Summers (1980). This experiment demonstrated that fermented cassava pulp can be used successfully on a nutritional basis to constitute up to $15 \%$ of the diet of broiler without negatively influencing growth, performance or carcass factor, and health due to their internal organs' parameters.

\section{CONCLUSION}

Fermented cassava pulp combined with $3 \%$ of urea and $2.5 \%$ of zeolite with six days of fermentation period have the best nutrition value due to the $\mathrm{CP}$ and $\mathrm{CF}$ concentration. True metabolized energy of fermented cassava pulp was lower compared to rice bran; however, the efficiency of protein utilization was higher. Fermented cassava pulp-urea-zeolite can be used successfully on a nutritional basis to constitute up to $15 \%$ of the diet of broiler without negatively influencing growth, performance and health.

ACKNOWLEDGMENT The authors wish to express their appreciation to the contributions of Faculty of Animal Science, Bogor Agricultural University, Indonesia, in terms of technical assistance, advice and general cooperation with the study.

\section{REFERENCES}

AOAC (Association of Official Analytical Chemists). 1984. Official Method of Analysis., 24th ed., Washington DC.

Barbarick, K. \& Pirella' H.G. 1984. Agronomic and holticulturral uses of zeolites. In: Pond, K. Industrial Microbiology. The AVI Publ. Co. Inc. Westport, Connecticut.

Brook, E.J., Stanton, W.R. \& Bridge, A.W. 1969. Fermentation methods for protein enrichment of cassava. Biotechnology \& Bioengineering, 11: 1271-1284.

DeMan, J.M. 1997. Chemical Nutrition. 2nd ed., ITB Bandung Press, Bandung.

FAO (Food and Agricultural Organization). 1995. Cassava. Cassava news letter, 19: 9.

Garraway, M.O. \& Evans, R.C. 1984. Fungal Nutrition and Physiology. John Wiley and Sons, New York.

Hall, I. 1980. Drying and Storage of agricultural crops. The AVI Publ. Co. Inc. Wesport, Connecticut.

Haroen, U. 1993. Pemanfaatan onggok dalam ransum dan pengaruhnya terhadap performans ayam broiler. Thesis. Graduate School of Bogor Agricultural University, Bogor.

Hartadi, H., Reksohadiprodjo, S. \& Tillman, A.D. 1997. Tables of Feed Composition for Indonesian. Gadjah Mada University Press, Yogyakarta.

Hendrinksen, H.V. \& Ahring, B.K. 1991. Effects of ammonia on growth and morphology of thermophilic hydrogen-oxidizing methanogenic bacteria. FEMS Microbiological Ecology, 85: 241-246.

Indonesian Central Bureau Statistic. 2000. Production of secondary food crops in Indonesia. Available at URL: http://www.bps.go.id/statbysection/agri/ pangan/ table $2 / \mathrm{html}$.

Iyayi, E.A. \& Losel, D.M. 2001. Protein enrichment of cassava byproducts through solid state fermentation by fungi. The Journal of Food Technology in Africa, 6: 116-118.

Lesson, S. \& Summers, D.J. 1980. Production and characteristic of broiler chicken. Poultry Science, 59: 786-798.

National Research Council. 1994. Nutrient Requirements of Poultry. 9th ed., National Academic Press. Washington DC.

Oboh, G. 2005. Nutrient enrichment of cassava peels using a mixed culture of Saccharomyces cerevisae and Lactobacilluss spp solid media fermentation 
techniques. Journal of Biotechnology, 9: 46-49.

Pandey, A., Soccol, C.R., Nigam, P., Soccol, V.T., Vandenberghe, L.P.S. \& Mohan, R. 2000. Biotechnologycal potential of agroindustrial residues. II: Cassava bagasse. Bioresource Technology, 74: 81-87.

Pepler, J.H. 1973. Yeast technology. The AVI Publ. Co. Inc. Wesport, Connecticut.

Pond, W.G. \& Mumpton, F.A. 1984. Zeo Agriculture (Use of Nature Zeolites in Agriculture and Aquaculture). International Committee on Natural Zeolites, Boulder, Colorado.

Prescot, S.C. \& Dunn, C.C. 1982. Industrial Microbiology. The AVI Publ. Co. Inc. Westport, Connecticut.

Putnam, P.A. 1991. Handbook of Animal Science. Academic Press, San Diego.

Ramos, A.J. \& Hernandez, E. 1997. Prevention of aflatoxicosis in farm animals by means of hydrated sodium calcium aluminosilicate addition to feedstuffs: a review. Animal Feed Science Technology, 65: 197-206.

Scott, M.L, Nesheim, M.C. \& Young, R.J. 1982. Nutrition of the Chicken. 3rd ed., M.L. Scott and Associates, Ithaca.

Sibbald, I.R. 1980. A new technique for estimating the ME content of feeds for poultry. In: FAO, Standardization of Analytic Methodology for Feeds. International Development Research Center, Canada.

Sriroth, K., Chollakup, R., Chotineeranat, S. Piyachomkwan, K. \& Oates, C.G. 2000. Processing of cassava waste for improved biomass utilization. Bioresource Technology, 71: 63-69.

Steel, R.G.D. \& Torrie, J.H. 1980. Principles and Procedures of Statistic, A Biometrical Approach. 2nd ed., McGraw-Hill International Book Co., Singapore.

Sundari, E. 1986. Toleransi ayam broiler terhadap kadungan serat kasar, serat detergen asam, lidnin dan silica dalam ransom yang mengandung tepung daun alang-alang. Ph.D Dissertation, Graduate School of Bogor Agricultural University, Bogor.

Wang, D.I.C, Coney, C.L., Demain, A.L., Dunnil, P, Humherey, A.F. \& Lily, M.D. 1979. Fermentation and Enzymes Technology. John Wiley and Sons, New York. 